\title{
molecules
}

ISSN 1420-3049

www.mdpi.com/journal/molecules

Article

\section{Design, Synthesis and Antiviral Potential of 14-Aryl/Heteroaryl-14H-dibenzo/a,j]xanthenes Using an Efficient Polymer-Supported Catalyst}

Kalla Reddi Mohan Naidu ${ }^{1}$, Balam Satheesh Krishna ${ }^{2}$, Mungara Anil Kumar ${ }^{3}$, Palanisamy Arulselvan ${ }^{4}$, Shaik Ibrahim Khalivulla ${ }^{5}$ and Ola Lasekan ${ }^{1, *}$

1 Department of Food Technology, Universiti Putra Malaysia, 43400 Serdang, Selangor, Malaysia

2 Department of Chemistry, Sri Venkateswara University, Tirupati 517502, India

3 Department of Nanomaterial Chemistry, Dongguk University, Gyeongju 780-714, Korea

4 Laboratory of Vaccines and Immunotherapeutics, Institute of Bioscience, Universiti Putra Malaysia, 43400 UPM Serdang, Selangor, Malaysia

5 Department of Pharmaceutical Chemistry, Faculty of Pharmaceutical Sciences, UCSI University, No.1, Jalan Menera Gading, 56000 Cheras, Kuala Lumpur, Malaysia

* Author to whom correspondence should be addressed; E-Mail: lasekan@food.upm.edu.my; Tel.: +603-8946-8535; Fax: +603-8948-5970.

Received: 11 May 2012; in revised form: 8 June 2012 / Accepted: 11 June 2012 /

Published: 18 June 2012

\begin{abstract}
Polyethyleneglycol bound sulfonic acid $\left(\mathrm{PEG}-\mathrm{OSO}_{3} \mathrm{H}\right)$, a chlorosulphonic acid-modified polyethylene glycol was successfully used as an efficient and eco-friendly polymeric catalyst in the synthesis of 14-aryl/heteroaryl-14H-dibenzo[a,j]xanthenes obtained from the reaction of 2-naphthol and carbonyl compounds under solvent-free conditions with short reaction times and excellent yields. The biological properties of these synthesized title compounds revealed that compounds $\mathbf{3 b}, \mathbf{3 c}, \mathbf{3 f}$ and $\mathbf{3 i}$ showed highly significant anti-viral activity against tobacco mosaic virus.
\end{abstract}

Keywords: aryl aldehydes; 2-naphthol; $\mathrm{PEG}-\mathrm{OSO}_{3} \mathrm{H}$; neat reaction; xanthenes; tobacco mosaic virus 


\section{Introduction}

Viral plant diseases originated from tobacco mosaic virus (TMV) are considered serious threats to modern agriculture worldwide. TMV is known to infect nine plant families and at least 125 individual species, such as tobacco, tomato, pepper, cucumbers and a number of ornamental flowers. The potential yield losses can fluctuate from 5 to $90 \%$, depending on the strain/severity of TMV such as the total time of infection, the optimal temperature during disease development/progression and the presence of other plant diseases. It is found that in certain fields $90-100 \%$ of the plants show mosaic or leaf necrosis by harvesting time. Several investigations have shown that TMV can modify plant phenotypes by destruction of mitochondria followed by damage of plant quality. As a result of this sequence, plant virus is also known as "plant cancer" and is difficult to prevent. So far, there are neither effective chemical treatments that fully protect plants from TMV infection nor any other factor that eliminates TMV from infected plants under field conditions [1].

In recent years polymer-supported compounds used as supported catalysts, reagents and scavengers have drawn the attention of researchers [2]. The utility of polymer-supported catalysts is well-recognized with their advantages like ease of workup, simple separation of products from the catalysts, economy and easily use in industrial processes [3]. The high reactivity, lack of diffusion phenomena, analytical simplicity and solubility profile of polyethylene glycols (PEGs with MW > 2,000 Da) as mostly soluble in polar solvents and insoluble in a few non-polar solvents have established them as good catalysts in homogeneous solid supported catalysis [4]. Rather than catalyst they are also used as a solvent for high temperature reactions as they melt at low temperatures [5]. Among them $\mathrm{PEG}-\mathrm{OSO}_{3} \mathrm{H}$ is a good example of solid supported organic acid catalyst that is functionalized with mild acidity, non-volatility and non-corrosiveness and also recognized as a good surfactant. It is reported that PEG-OSO $3 \mathrm{H}_{3}$ had been used for the synthesis of 3,4-dihydropyrimidones via the Biginelli reaction [5], regioselective ring opening of epoxides with thiocyanate anion [6], Beckmann rearrangement and dehydration of oximes [7] and synthesis of bis(indolyl)methanes and 4,4'-(arylmethylene)-bis(3methyl-1-phenyl-1H-pyrazol-5-ols) [8].

Aryl-14H-dibenzo[a,j]xanthenes are reported as important antibacterial, antiviral and anti-inflammatory agents [9-11]. In addition to their biological applications they also applied in photodynamic therapy [12], in industries as dyes, in laser technology and as fluorescent materials for visualization of biomolecules [13-15]. These benzoxanthenes were synthesized from the reaction of 2-naphthol with formamide [16], $\beta$-hydroxynaphthyl carbinol with resorcinol [17], and from the action of hot alkali on 2-naphthyl oxide [18]. The xanthene synthesis is catalyzed by some catalysts like $p$-toluenesulfonic acid [19], sulfamic acid [20], $\mathrm{AcOH} / \mathrm{H}_{2} \mathrm{SO}_{4}$ [15], iodine [21,22], $\mathrm{K}_{5} \mathrm{CoW}_{12} \mathrm{O}_{40} \cdot 3 \mathrm{H}_{2} \mathrm{O}$ [23], cyanuric chloride [24], $\mathrm{LiBr}$ [25], $\mathrm{HClO}_{4} \cdot \mathrm{SiO}_{2}$ [26], $\mathrm{KAl}\left(\mathrm{SO}_{4}\right)_{2} \cdot 12 \mathrm{H}_{2} \mathrm{O}$ [27], silica sulfuric acid [28] and $\mathrm{Yb}(\mathrm{OTf})_{3}$ [29]. However, there is a need to find new catalysts and green methods to minimize the drawbacks of existing methods such as poor yields, prolonged reaction times, toxic organic solvents, excess reagents, catalysts and harsh reaction conditions so here we are reporting $\mathrm{PEG-OSO}{ }_{3} \mathrm{H}$ as a catalyst for this reaction and to the best of our knowledge, this is also the first investigation on the anti-TMV bioactivity of xanthenes designed in this article. 


\section{Results and Discussion}

\subsection{Chemistry}

To examine non-hazardous methods for the transformations which occur in organic synthesis herein we report a highly versatile and efficient synthesis of aryl/heteroaryl-14H-dibenzo[a,j]xanthenes 3a-i (Scheme 1) from two equivalents of 2-naphthol (1) and one equivalent of various aryl aldehydes $\mathbf{2 a - i}$, and catalytic amounts of a polymer-supported acidic catalyst. In a typical reaction, a 2:1 mixture of 1 and $2 \mathrm{a}$ and a catalytic amount of PEG-OSO${ }_{3} \mathrm{H}(1 \mathrm{~mol} \%)$ was placed in a $50 \mathrm{~mL}$ flat-bottomed flask and heated for 30-60 min on a hot plate at $60-65{ }^{\circ} \mathrm{C}$ under solvent free condition to produce 3a in excellent yield. The same reactions conditions were applied for the synthesis of the remaining series of compounds $\mathbf{2 b}-\mathbf{i}$ as presented in Scheme 1 and summarized in Table 1.

Scheme 1. Synthesis of 14-aryl/heteroaryl-14H-dibenzo[a,j]xanthenes.

a. Synthesis of 14 -aryl-14H-dibenzo[a,j]xanthene from $\beta$-naphthol and Various aryl aldehydes

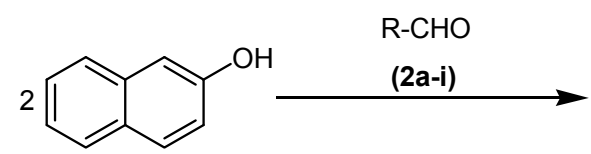

(1)<smiles>[R]C1c2c(ccc3ccccc23)Oc2ccc3ccccc3c21</smiles>

(3a-i)

b. Synthesis of 1,4-bis(7H-dibenzo[c,h]xanthen-7-yl)piperazine from $\beta$-naphthol and piperazine-1,4-dicarbaldehyde<smiles>O=CN1CCN(C2c3ccc4ccccc4c3Oc3c2ccc2ccccc32)CC1</smiles>

(5)

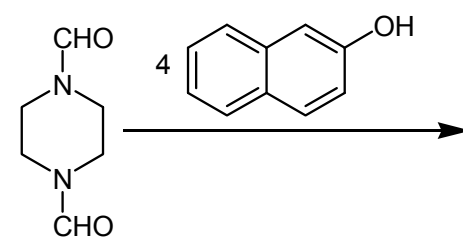

(4)<smiles>c1ccc2c3c(ccc2c1)C(N1CCN(C2c4ccc5ccccc5c4Oc4c2ccc2ccccc42)CC1)c1ccc2ccccc2c1O3</smiles>

(6)

c. Synthesis of 9,9-dimethyl-12-(pyridin-2-yl)-9,10-dihydro-8H-benzo[a]xanthen-11(12H)-one from $\beta$-naphthol, picolinaldehyde and 5,5-dimethylcyclohexane-1,3-dione<smiles>CC1CC(=O)CC(C)(C)C1</smiles>

(8)<smiles>CC1(C)CC(=O)C2=C(C1)Oc1ccc3ccccc3c1C2c1ccccn1</smiles>

(9)

Reaction Conditions: Neat, $60-65^{\circ} \mathrm{C}$ Catalyst: $\mathrm{PEG}-\mathrm{SO}_{3} \mathrm{H}$ 
Table 1. Synthesis of xanthenes catalyzed by $\mathrm{PEG}-\mathrm{OSO}_{3} \mathrm{H}$ at $60-65{ }^{\circ} \mathrm{C}$ from 2-naphthols, aldehydes and cyclic 1,3-dicarbonyl compounds.

\begin{tabular}{|c|c|c|c|c|c|c|}
\hline \multirow{2}{*}{ Entry } & \multirow{2}{*}{ Product } & \multirow{2}{*}{$\mathbf{R}$} & \multirow{2}{*}{ Time (min) } & \multirow{2}{*}{ Yield $(\%)^{a}$} & \multicolumn{2}{|c|}{ Melting Point $\left({ }^{\circ} \mathrm{C}\right)$} \\
\hline & & & & & Found & Literature [Ref.] \\
\hline 1 & $\mathbf{3 a}$ & & 20 & 96 & $181-182$ & $182-183[30]$ \\
\hline 2 & $3 \mathbf{b}$ & & 15 & 92 & $310-312$ & $311-313[30]$ \\
\hline 3 & $3 c$ & & 22 & 96 & $290-291$ & $292-293[30]$ \\
\hline 4 & 3d & & 18 & 91 & $203-205$ & 204-205 [30] \\
\hline 5 & $3 e$ & & 24 & 95 & $163-164$ & $163-165[31]$ \\
\hline 6 & $3 f$ & & 21 & 90 & $286-287$ & $287-288[30]$ \\
\hline 7 & $3 g$ & & 25 & 93 & $173-174$ & $172-173[30]$ \\
\hline 8 & $3 \mathbf{h}$ & & 30 & 85 & $206-207$ & $208-210[32]$ \\
\hline 9 & $3 \mathbf{i}$ & & 20 & 97 & $178-179$ & - \\
\hline 10 & 5 & & 25 & 90 & $183-184$ & - \\
\hline 11 & 6 & & 30 & 94 & $185-187$ & - \\
\hline 12 & 9 & & 32 & 92 & 179-181 & - \\
\hline
\end{tabular}

${ }^{\mathrm{a}}$ Isolated yield.

During our study on the dehydration of 2-naphthol by various aldehydes under solvent-free condition at $80{ }^{\circ} \mathrm{C}$, we made an interesting observation that $5 \mathrm{~mL}$ of PEG-600 catalyzed the reaction. 2-Naphthol underwent dehydration with benzaldehyde leading to aryl or heteroaryl-14H-dibenzo $[a, j]$ xanthenes after long reaction times and the yields were very low.

The same method was employed in the presence of catalytic amount of chlorosulphonic acid supported PEG-6000 (1 mol \%) and we found it as an efficient catalyst which brought this reaction to completion at $65{ }^{\circ} \mathrm{C}$ in the absence of solvent. Blank experiments have shown that the chlorosulphonoic acid alone could not bring about this transformation. In addition, it was observed that only $1 \mathrm{~mol} \%$ of $\mathrm{PEG}-\mathrm{OSO}_{3} \mathrm{H}$ is sufficient for the formation of xanthenes. Encouraged by the results obtained for benzaldehyde and other aldehydes, the reaction was further studied under the current 
catalytic conditions with a variety of carbonyl (aromatic and heterocyclic aldehydes) compounds. All the carbonyl substrates reacted smoothly with 2-naphthol to produce xanthenes (Table 1) in high yields under these reaction conditions $\left(60-65^{\circ} \mathrm{C} ; 30-60 \mathrm{~min}\right)$. The electronic nature of the substituent in the aromatic ring did not show any noticeable effect on this conversion.

Additionally, we also investigated the recyclability of $\mathrm{PEG}-\mathrm{OSO}_{3} \mathrm{H}$ for three consecutive cycles (fresh +3 cycles) for the synthesis of 14-phenyl-14H-dibenzo[a,j]xanthenes (3a). 2-Naphthol was treated with benzaldehyde in the presence of $1 \mathrm{~mol} \%$ catalyst under neat conditions for $20 \mathrm{~min}$. After completion of the reaction, $\mathrm{PEG}-\mathrm{OSO}_{3} \mathrm{H}$ was extracted with water and reused after the evaporation of aqueous layer under reduced pressure. The above sequence was repeated three times to produce the product 3a in good yields without any significant loss in the catalytic activity of $\mathrm{PEG}-\mathrm{OSO}_{3} \mathrm{H}$ (Table 2).

Table 2. Recyclability of the $\mathrm{PEG}-\mathrm{OSO}_{3} \mathrm{H}$ for the one-pot condensation reaction of 2-naphthol with benzaldehyde under neat condition.

\begin{tabular}{cccc}
\hline Entry & Recovery & Time/min & Yields $^{\mathbf{a}} \mathbf{( \% )}$ \\
\hline 1 & 0 & 20 & 96 \\
2 & 1 & 20 & 95 \\
3 & 2 & 20 & 93 \\
4 & 3 & 20 & 92 \\
\hline
\end{tabular}

${ }^{\mathrm{a}}$ Isolated yields for xanthene (3a) after each cycle.

The same reaction procedure was followed for the synthesis of remaining xanthene derivatives, i.e., monofunctionalized xanthene derivative 4-(14H-dibenzo[a,j]xanthen-14-yl)piperazine-1-carbaldehyde (5) and bifunctionalized xanthene derivative 7-(1-(14H-dibenzo[a,j]xanthen-14-yl)piperidin-4-yl)-7Hdibenzo[c,h]phenoxazine (6) from the reaction of piperazine-1,4-dicarbaldehyde with 2-naphthol. Similarly 9,9-dimethyl-12-(pyridin-2-yl)-9,10-dihydro-8H-benzo[a]xanthen-11(12H)-one (9) was also synthesized from the reaction of 2-naphthol, 2-picolinaldehyde and 5,5-dimethylcyclohexane-1,3dione as given in Scheme 1. Preliminary data for these compounds were provided in Table 1.

\subsection{Biology}

Ningnanmycin is a commercial antiviral agent, isolated from Strepcomces noursei var. xichangensisn by the Chengdu Institute of Biology, Chinese Academy of Sciences. It is a kind of well-known microbial pesticide that imparts its action by destruction of the coat protein of TMV, thereby inducing plant host resistance pathways. It is more effective in the treatment of plants against TMV than the other accessible commercial agents used in the agro-pharmaceutical industry [33]. However, the use of this agent for field trials is largely very limited by its photosensitivity and water stickiness [34]. Therefore, further extensive investigations needs to be conducted in this related area for the development of a highly efficient, economical, novel, and environmentally benign antiviral agent. In this present investigation, we used ningnanmycin as a positive control for comparison of viral activities. In this study it was observed that basic xanthene moiety of compounds showed highly significant anti-viral activity against tobacco mosaic virus replication, as depicted in Figure 1, most of our designed compounds exhibited good antiviral properties. 
Figure 1. The anti-TMV activity of the synthesized compounds.

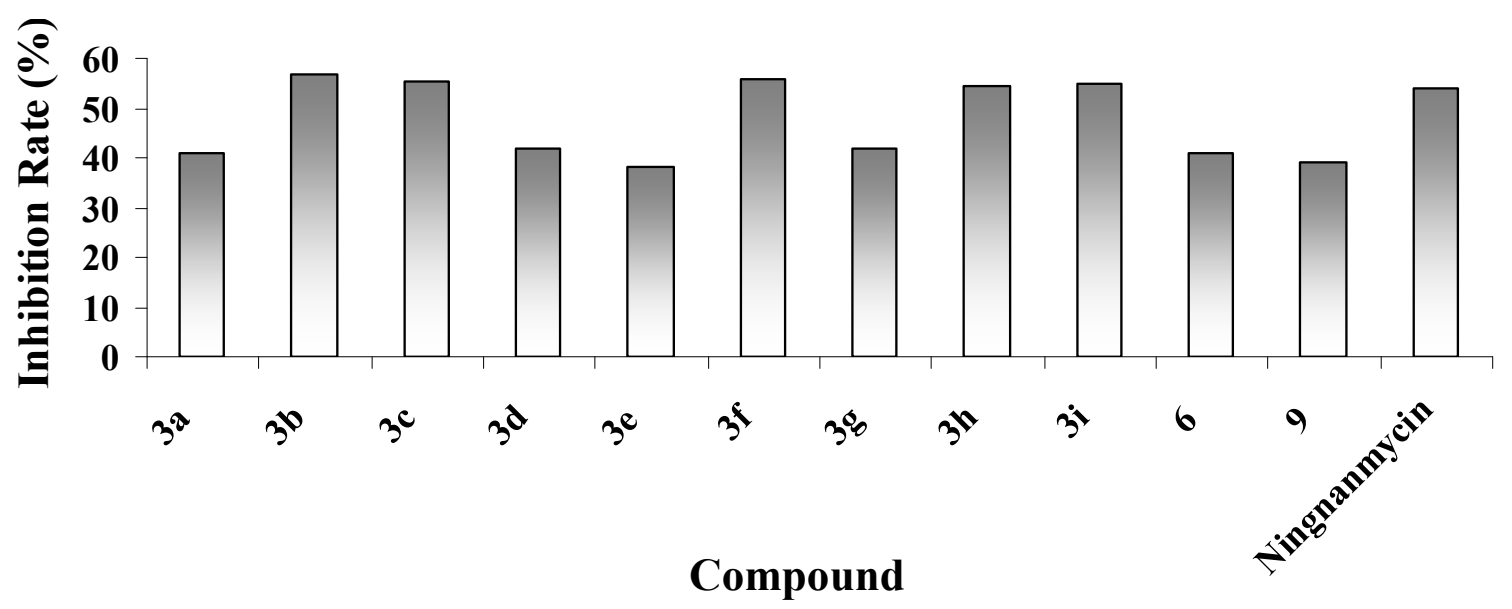

The basic polynuclear structural framework (tetracyclic and pentacyclic nuclei) in all synthesized compounds containing an alkenyl functionality in conjugation to the oxygen atom of the xanthene nucleus is the basic structural requirement for the exhibition of antiviral activity which was previously reported for the compounds with the basic skeletons like fluorenone and anthraquinone derivatives. Similarly the abovementioned structural features were also attributed the antiviral activity of the compounds in the present study. Further, on comparison of all these analogues, $\mathbf{3 b}$ afforded potent viral activity which is comparable to that of ningnanmycin. However, in most cases, the piperazine1,4-dicarbaldehyde had no distinct influence on the antiviral activity. In addition, the introduction of electron-withdrawing groups $(\mathbf{3 b}, \mathbf{3 c}, \mathbf{3 f}, \mathbf{3 g}$ and $\mathbf{3 i})$ resulted in higher antiviral potential than the corresponding analogues with electron-donating groups (3d, $\mathbf{3 e}$ and $\mathbf{3 h})$. The corresponding compound 6 showed lower inhibitory efficiency, which is possibly due, in part, to the relatively rigid structure. On the basis of these observed results it may be speculated that the antiviral activity of xanthenes group of compounds are primarily due to the presence of nitrogenous groups, which can prevent/ manage the host plant from initial infection/ replication by virus.

\section{Experimental}

\subsection{General}

All chemicals were purchased from Sigma-Aldrich and were used without further purification. IR spectra were recorded on a Perkin-Elmer 683 spectrophotometer using $\mathrm{KBr}$ optics. ${ }^{1} \mathrm{H}-$ and ${ }^{13} \mathrm{C}-\mathrm{NMR}$ spectra were recorded on Bruker Avance $300 \mathrm{MHz}$ NMR spectrometer operating at $300 \mathrm{MHz}$ for ${ }^{1} \mathrm{H}-\mathrm{NMR}$ and $75 \mathrm{MHz}$ for ${ }^{13} \mathrm{C}-\mathrm{NMR}$. NMR data recorded in $\mathrm{CDCl}_{3}$ and referenced to TMS $\left({ }^{1} \mathrm{H}\right.$ and ${ }^{13} \mathrm{C}$ ). Mass spectra were recorded on a JEOL GCMATE II GC-MS spectrometer at SAIF, IIT Madras (Chennai, India).

\subsection{Catalyst Preparation}

At $0{ }^{\circ} \mathrm{C}$, chlorosulfonic acid $(1.16 \mathrm{~g}, 10 \mathrm{mmol})$ was added to a solution of PEG-6000 (6.0 g, $1 \mathrm{mmol}$ ) in $5 \mathrm{~mL}$ of $\mathrm{CH}_{2} \mathrm{Cl}_{2}$. Then the resulting solution was stirred at room temperature overnight, and the solution was concentrated under vacuum. Then diethyl ether $(5 \mathrm{~mL})$ was added and the 
precipitated product was filtered and washed with diethyl ether three times to afford the purified $\mathrm{PEG}-\mathrm{OSO}_{3} \mathrm{H}[7]$.

\subsection{General Procedure for the Synthesis of 14-(4-Chloro-3-nitrophenyl)-14H-dibenxo[a,j]xanthenes}

$\mathbf{3 a}-\mathbf{i}$

2-Naphthol (1, $0.29 \mathrm{~g}, 2 \mathrm{mmol})$ and benzaldehyde (2a, $0.10 \mathrm{~g}, 1 \mathrm{mmol})$ were mixed in the presence of $\mathrm{PEG}-\mathrm{OSO}_{3} \mathrm{H}$ catalyst. The resulting mixture was then stirred for $30 \mathrm{~min}$ at $60-65{ }^{\circ} \mathrm{C}$. After the completion of the reaction (as indicated by TLC), the reaction mixture was poured into ice water and the obtained solid was collected by filtration, washed with water and then dried. The obtained solid was recrystallised from hot ethanol.

The physical and spectral data of known compounds $\mathbf{3 a}-\mathbf{h}$ were found to be in agreement with the reported data [30-32] while the characterization data of newly synthesized products 3i, 5, 6 and 9 are given below.

After completion of the reaction, water was added to the reaction mixture and was shaken to dissolve $\mathrm{PEG}-\mathrm{OSO}_{3} \mathrm{H}$ in it. Then in order to recover the catalyst, water was evaporated under reduced pressure, and the resulting solid was washed with diethyl ether, and dried. The recovered catalyst was reused four times for the subsequent reactions without loss of potentiality in catalytic activity [35].

14-Phenyl-14H-dibenzo[a,j]xanthene (3a). Pale yellow solid, m.p.: $181-182{ }^{\circ} \mathrm{C}$. IR (KBr) $v_{\max }: 3068$, 3020, 2885, 1620, 1590, 1512, 1488, 1457, 1402, 1252, 1080, 1025, 965, 825, 745, $700 \mathrm{~cm}^{-1} .{ }^{1} \mathrm{H}-\mathrm{NMR}$ $\left(\mathrm{CDCl}_{3}\right): \delta 8.40(\mathrm{~d}, J=8.4 \mathrm{~Hz}, 2 \mathrm{H}), 7.82(\mathrm{~d}, J=7.9 \mathrm{~Hz}, 2 \mathrm{H}), 7.79(\mathrm{~d}, J=8.8 \mathrm{~Hz}, 2 \mathrm{H}), 7.58(\mathrm{t}, J=7.7 \mathrm{~Hz}$, 2H), $7.53(\mathrm{~d}, J=7.5 \mathrm{~Hz}, 2 \mathrm{H}), 7.49$ (d, $J=8.8 \mathrm{~Hz}, 2 \mathrm{H}), 7.41-7.00(\mathrm{~m}, 5 \mathrm{H}), 6.49$ (s, 1H, Ar-CH). ${ }^{13} \mathrm{C}-\mathrm{NMR}\left(\mathrm{CDCl}_{3}\right): \delta 148.1,145.5,131.4,131.8,128.7,128.2,128.1,126.8,126.5,126.3,124.2$, 122.3, 117.1, 117.5, 38.3. EI-MS: $m / z(\%) 358\left(\mathrm{M}^{+}\right)$; Anal. Calcd. for $\mathrm{C}_{27} \mathrm{H}_{18} \mathrm{O}: \mathrm{C}, 90.47 ; \mathrm{H}, 5.06$. Found: C, 90.41; H, 5.14.

14-(4-Nitrophenyl)-14H-dibenzo[a,j]xanthene (3b). Yellow solid, m.p.: $310-312{ }^{\circ} \mathrm{C}$. IR ( $\left.\mathrm{KBr}\right) v_{\max }$ : 3062, 2931, 1629, 1595, 1527, 1453, 1401, 1346, 1200, 1141, 1108, 1015, 965, 850, 828, 810, $743 \mathrm{~cm}^{-1} .{ }^{1} \mathrm{H}-\mathrm{NMR}\left(\mathrm{CDCl}_{3}\right): \delta 8.30(\mathrm{~d}, J=8.5 \mathrm{~Hz}, 2 \mathrm{H}), 7.98(\mathrm{~d}, J=8.7 \mathrm{~Hz}, 2 \mathrm{H}), 7.85-7.45(\mathrm{~m}, 12 \mathrm{H}$, $\mathrm{ArH}), 6.60(\mathrm{~s}, 1 \mathrm{H}, \mathrm{Ar}-\mathrm{CH}) .{ }^{13} \mathrm{C}-\mathrm{NMR}\left(\mathrm{CDCl}_{3}\right): \delta 152.5,148.0,145.8,135.1,130.9,130.7,129.7$, 128.6, 127.3, 124.7, 123.5, 123.0, 117.8, 116.2, 36.5. EI-MS: $m / z(\%) 403\left(\mathrm{M}^{+}\right)$. Anal. Calcd. for $\mathrm{C}_{27} \mathrm{H}_{17} \mathrm{NO} 3$ : C, 80.38; H, 4.25; N, 3.47. Found: C, 80.30; H, 4.35; N, 3.55.

14-(2-Nitrophenyl)-14H-dibenzo[a,j]xanthene (3c). Yellow solid, m.p.: 290-291 ${ }^{\circ} \mathrm{C}$. IR (KBr) $v_{\max }$ : $3402,3056,2928,1615,1594,1524,1352,1243,1140,815,750 \mathrm{~cm}^{-1} .{ }^{1} \mathrm{H}-\mathrm{NMR}\left(\mathrm{CDCl}_{3}\right): \delta 8.59-7.15$ $(\mathrm{m}, 16 \mathrm{H}), 7.54(\mathrm{~s}, 1 \mathrm{H}) .{ }^{13} \mathrm{C}-\mathrm{NMR}\left(\mathrm{CDCl}_{3}\right): \delta 150.1,147.8,141.3,134.5,132.7,132.0,130.5,129.8$, 129.6, 129.2, 128.1, 127.6, 125.5, 125.1, 124.5, 122.9, 118.5, 118.1, 33.1. EI-MS: $m / z(\%) 403\left(\mathrm{M}^{+}\right)$. Anal. Calcd. for $\mathrm{C}_{27} \mathrm{H}_{17} \mathrm{NO}_{3}$ : C, 80.38; H, 4.25; N, 3.47. Found: C, 80.23; H, 4.31; N, 3.54.

14-(4-Methoxyphenyl)-14H-dibenzo[a,j]xanthene (3d). Yellow solid, m.p.: 203-205 ${ }^{\circ} \mathrm{C}$. IR (KBr) $v_{\max }$ : 3041, 2913, 1615, 1582, 1511, 1465, 1433, 1404, 1250, 1122, 1088, 968, 825, 805, $748 \mathrm{~cm}^{-1} .{ }^{1} \mathrm{H}-\mathrm{NMR}$ $\left(\mathrm{CDCl}_{3}\right): \delta 8.41(\mathrm{~d}, J=8.3 \mathrm{~Hz}, 2 \mathrm{H}), 7.83(\mathrm{~d}, J=8.2 \mathrm{~Hz}, 2 \mathrm{H}), 7.72(\mathrm{~d}, J=8.3 \mathrm{~Hz}, 2 \mathrm{H}), 7.58-6.71(\mathrm{~m}$, 
$10 \mathrm{H}, \mathrm{ArH}), 6.51(\mathrm{~s}, 1 \mathrm{H}), 3.70(\mathrm{~s}, 3 \mathrm{H}) .{ }^{13} \mathrm{C}-\mathrm{NMR}\left(\mathrm{CDCl}_{3}\right): \delta 158.2,149.5,137.1,134.2,131.4,130.1$, 129.6, 129.2, 127.8, 124.9, 123.1, 118.6, 117.8, 114.5, 54.1, 37.4. EI-MS: $m / z(\%) 388\left(\mathrm{M}^{+}\right)$. Anal. Calcd. for $\mathrm{C}_{28} \mathrm{H}_{20} \mathrm{O}_{2}$ : C, 86.57; H, 5.19. Found: C, 86.44; H, 5.23.

14-(3-Methoxyphenyl)-14H-dibenzo[a,j]xanthene (3e). Yellow solid, m.p.: $163-164{ }^{\circ} \mathrm{C}$. IR (KBr) $v_{\max }$ : 3013, 2951, 2936, 1594, 1487, 1453, 1439, 1400, $1250 \mathrm{~cm}^{-1} .{ }^{1} \mathrm{H}-\mathrm{NMR}\left(\mathrm{CDCl}_{3}\right) \delta 8.38(\mathrm{~d}, 2 \mathrm{H}, J=8.4 \mathrm{~Hz})$. 7.80-7.72 (m, 4H), 7.65-7.31 (m, 6H), 7.01-6.53 (m, 4H), 6.41 (s, 1H), 3.61 (s, 3H). ${ }^{13} \mathrm{C}-\mathrm{NMR}$ (CDCl3): $\delta 152.6,148.8,146.4,131.3,131.0,129.2,128.8,128.5,126.7,124.3,122.8,120.8,118.4$, 117.1, 115.2, 111.4, 55.6, 38.3, Anal.Calcd. for $\mathrm{C}_{28} \mathrm{H}_{20} \mathrm{O}_{2}$ : C, 86.45; H, 5.06. Found: C, 86.53; H, 5.14.

14-(4-Chlorophenyl)-14H-dibenzo[a,j]xanthene (3f). Brown solid, m.p.: 286-287 ${ }^{\circ} \mathrm{C}$. IR (KBr) $v_{\max }$ : 3050, 2926, 1620, 1594, 1456, 1438, 1393, 1242, 1061, 960, 826, 778, $695 \mathrm{~cm}^{-1} .{ }^{1} \mathrm{H}-\mathrm{NMR}\left(\mathrm{CDCl}_{3}\right): \delta$ $8.45(\mathrm{~d}, J=8.5 \mathrm{~Hz}, 2 \mathrm{H}), 8.01(\mathrm{~d}, J=8.7 \mathrm{~Hz}, 2 \mathrm{H}), 7.88-7.50(\mathrm{~m}, 12 \mathrm{H}), 7.46(\mathrm{~s}, 1 \mathrm{H}) .{ }^{13} \mathrm{C}-\mathrm{NMR}$ $\left(\mathrm{CDCl}_{3}\right): \delta 156.1,147.5,132.3,131.2,129.8,128.1,128.6,127.0,126.8,126.5,124.7,119.3,118.2$, 117.8, 33.3. EI-MS: $m / z(\%) 392\left(\mathrm{M}^{+}\right)$. Anal. Calcd. for $\mathrm{C}_{27} \mathrm{H}_{17} \mathrm{ClO}$ : C, 82.54; H, 4.36. Found: C, $82.42 ; \mathrm{H}, 4.41$.

14-(3-Chlorophenyl)-14H-dibenzo[a,j]xanthene (3g). Brown solid, m.p.: $173-174{ }^{\circ} \mathrm{C}$. IR (KBr) $v_{\max }$ : 3053, 2924, 1621, 1592, 1508, 1455, 1430, 1398, 1245, 1064, 959, 815, 775, 748, $691 \mathrm{~cm}^{-1} .{ }^{1} \mathrm{H}-\mathrm{NMR}$ $\left(\mathrm{CDCl}_{3}\right): \delta 8.30-6.96(\mathrm{~m}, 16 \mathrm{H}, \mathrm{ArH}), 6.45(1 \mathrm{H}, \mathrm{s}) .{ }^{13} \mathrm{C}-\mathrm{NMR}\left(\mathrm{CDCl}_{3}\right): \delta 148.1,146.3,134.2,131.6$, $131.0,129.6,129.1,128.1,128.0,127.2,126.8,126.4,124.5,122.4,118.1,116.4,37.6$. EI-MS: $\mathrm{m} / z$ (\%) $392\left(\mathrm{M}^{+}\right)$. Anal. Calcd. for $\mathrm{C}_{27} \mathrm{H}_{17} \mathrm{ClO}$ : C, 82.54; H, 4.36. Found: C, 82.47; H, 4.43.

14-(4-Hydroxy-3-methoxyphenyl)-14H-dibenzo[a,j]xanthene (3h). Yellow solid, m.p.: 206-207 ${ }^{\circ} \mathrm{C}$. IR (KBr) $v_{\max }: 3020,2399,1593,1508,1431,1215 \mathrm{~cm}^{-1} .{ }^{1} \mathrm{H}-\mathrm{NMR}\left(\mathrm{CDCl}_{3}\right): 8.39$ (d, 2H, $\left.J=8.30 \mathrm{~Hz}\right)$, 7.76-7.84 (m, 4H), 7.37-7.58 (m, 6H), 7.12-7.16 (m, 1H), $6.82(\mathrm{~d}, 1 \mathrm{H}, J=2.14 \mathrm{~Hz}), 6.71(\mathrm{~d}, 1 \mathrm{H}$, $J=8.0 \mathrm{~Hz}), 3.64(\mathrm{~s}, 3 \mathrm{H}), 6.42(\mathrm{~s}, 1 \mathrm{H}), 5.32(\mathrm{~s}, 1 \mathrm{H}) .{ }^{13} \mathrm{C}-\mathrm{NMR}\left(\mathrm{CDCl}_{3}\right): 151.9,150.5,147.5,140.2$, 134.7, 134.3, 132.0, 129.9, 127.5, 126.0, 124.2, 121.1, 120.8, 117.5, 114.6, 58.9, 40.8. Anal. Calcd. for $\mathrm{C}_{28} \mathrm{H}_{20} \mathrm{O}_{3}$ : C, 83.15; H, 4.98. Found: C, 83.02; H, 4.88.

14-(4-Chloro-3-nitrophenly)-14H-dibenxo[a,j]xanthene (3i). Yellow solid, m.p.: $178-179{ }^{\circ} \mathrm{C}$. IR $(\mathrm{KBr}) v_{\max }: 3157,1412,1231,820,746 \mathrm{~cm}^{-1} .{ }^{1} \mathrm{H}-\mathrm{NMR}\left(\mathrm{CDCl}_{3}\right): \delta 8.24-7.24(\mathrm{~m}, 15 \mathrm{H}, \mathrm{Ar}-\mathrm{H}), 6.54(\mathrm{~s}$, $1 \mathrm{H}, \mathrm{Ar}-\mathrm{CH}) .{ }^{13} \mathrm{C}-\mathrm{NMR}\left(\mathrm{CDCl}_{3}\right): \delta 151.6,147.2,142.3,132.3,128.1,127.1,126.1,125.4,122.6$, 122.1, 117.6, 114.3, 125.1, 134.2, 129.6, 124.2, 46.1. EI-MS: $476(\mathrm{M}+\mathrm{K})$.

\subsection{Procedure for the Synthesis of 4-(14H-Dibenzo[a,j]xanthen-14-yl)piperazine-1-carbaldehyde (5)}

2-Naphthol (1, $0.29 \mathrm{~g}, 2 \mathrm{mmol})$ and piperazine-1,4-dicarbaldehyde (4, $0.14 \mathrm{~g}, 1 \mathrm{mmol})$ were mixed in the presence of $\mathrm{PEG}-\mathrm{OSO}_{3} \mathrm{H}$ catalyst $(1 \mathrm{~mol} \%)$. The resulting mixture was then stirred for $30 \mathrm{~min}$ at $60-65{ }^{\circ} \mathrm{C}$. After the completion of the reaction (as indicated by TLC), the reaction mixture was poured into ice water and the obtained solid was collected by filtration, washed with water and then dried. Green solid, m.p.: 183-184 ${ }^{\circ} \mathrm{C}$. IR (KBr) $v_{\max }: 3153,1614,1410,1234,746 \mathrm{~cm}^{-1}$. ${ }^{1} \mathrm{H}-\mathrm{NMR}$ $\left(\mathrm{CDCl}_{3}\right): \delta 7.83(\mathrm{~s}, 1 \mathrm{H},-\mathrm{CHO}), 7.36-6.60(\mathrm{~m}, 12 \mathrm{H}, \mathrm{Ar}-\mathrm{H}), 5.87(\mathrm{~s}, 1 \mathrm{H}, \mathrm{Ar}-\mathrm{CH}), 1.35-1.20(\mathrm{~m}, 8 \mathrm{H}$, 
$\left.-\mathrm{N}-\mathrm{CH}_{2}\right) .{ }^{13} \mathrm{C}-\mathrm{NMR}\left(\mathrm{CDCl}_{3}\right)$ : d 153.4, 151.3, 136.6, 127.3, 123.4, 121.7, 120.0, 119.40, 119.0, 116.6, 111.8, 56.6, 55.5, 32.1. EI-MS: $394\left(\mathrm{M}^{+}\right), 412\left(\mathrm{M}+\mathrm{NH}_{4}{ }^{+}\right)$.

3.5. Procedure for the Synthesis of 7-(1-(14H-dibenzo[a,j]xanthen-14-yl)piperidin-4-yl)-7H-dibenzo$[c, h]$ phenoxazine $(\mathbf{6})$

2-Naphthol (1, $0.58 \mathrm{~g}, 4 \mathrm{mmol})$ and piperazine-1,4-dicarbaldehyde (4, $0.14 \mathrm{~g}, 1 \mathrm{mmol})$ were mixed in presence of $\mathrm{PEG}-\mathrm{OSO}_{3} \mathrm{H}$ catalyst $(1 \mathrm{~mole} \%)$. The resulting mixture was then stirred for $30 \mathrm{~min}$ at $60-65^{\circ} \mathrm{C}$. After the completion of the reaction (as indicated by TLC), the reaction mixture was poured into ice water and the obtained solid was collected by filtration, washed with water and then dried. Light greenish solid, m.p.: $185-187{ }^{\circ} \mathrm{C}$; IR (KBr) $v_{\max }$ : 3157, 1412, 1231, 820, $746 \mathrm{~cm}^{-1}$; ${ }^{1} \mathrm{H}-\mathrm{NMR}$ (CDCl3): $\delta 8.26-7.35(\mathrm{~m}, 24 \mathrm{H}, \mathrm{Ar}-\mathrm{H}), 7.25$ (s, 2H, Ar-CH), 1.40-1.6 (m, 8H, -N-CH $)$; APCI-MS: $664\left(\mathrm{M}+\mathrm{NH}_{4}^{+}\right)$.

3.6. Procedure for the Synthesis of 9,9-Dimethyl-12-(pyridin-2-yl)-9,10-dihydro-8H-benzo[a]xanthen11(12H)-one (9)

2-Naphthol (1, $0.14 \mathrm{~g}, 1 \mathrm{mmol})$, 2-picolinaldehyde (7, $0.10 \mathrm{~g}, 1 \mathrm{mmol})$ and 5,5-dimethylcyclohexane-1,3-dione $(8,0.14 \mathrm{~g}, 1 \mathrm{mmol})$ were mixed in presence of $\mathrm{PEG}-\mathrm{OSO}_{3} \mathrm{H}$ catalyst $(1 \mathrm{~mol} \%)$. The resulting mixture was then stirred for $30 \mathrm{~min}$ at $60-65{ }^{\circ} \mathrm{C}$. After the completion of the reaction (as indicated by TLC), the reaction mixture was poured into ice water and the obtained solid was collected by filtration, washed with water and then dried. White solid, m.p.: $179-181{ }^{\circ} \mathrm{C}$. IR (KBr) $v_{\max }: 2950$, 1670, 1630, 1545, 1350, 1220, 1150, $102 \mathrm{~cm}^{-1} .{ }^{1} \mathrm{H}-\mathrm{NMR}\left(\mathrm{CDCl}_{3}\right): \delta 6.55-8.05(\mathrm{~m}, 10 \mathrm{H}, \mathrm{ArH}), 5.62$ $(\mathrm{s}, 1 \mathrm{H}, \mathrm{CH}), 2.55\left(\mathrm{~s}, 2 \mathrm{H}, \mathrm{CH}_{2}\right), 2.26\left(\mathrm{~s}, 2 \mathrm{H}, \mathrm{CH}_{2}\right) 1.10\left(\mathrm{~s}, 3 \mathrm{H}, \mathrm{CH}_{3}\right), 0.99\left(\mathrm{~s}, 3 \mathrm{H}, \mathrm{CH}_{3}\right) .{ }^{13} \mathrm{C}-\mathrm{NMR}$ $\left(\mathrm{CDCl}_{3}\right): \delta 197.6,164.1,149.4,148.2,133.8,132.1,132.0,129.5,128.9,128.8,127.4,125.2,124.3$, $118.8,117.5,115.2,112.9,51.5,41.9,41.1,34.1,32.8,29.7,27.9$. EI-MS (\%): $355\left(\mathrm{M}^{+}\right)$.

\subsection{Antiviral Activity}

\subsubsection{Purification of Tobacco Mosaic Virus (TMV)}

Using Goodings' method [36], the upper leaves of Nicotiana tabacum L inoculated with TMV were selected and ground in a phosphate buffer, then filtered through double layer pledget. The filtrate was centrifuged at 10,000 g, treated twice with PEG and centrifuged again. The whole experiment was carried at $4{ }^{\circ} \mathrm{C}$. Absorbance values were measured at $260 \mathrm{~nm}$ using an ultraviolet spectrophotometer:

$$
\text { Virus concentrat ion }=\frac{A_{260} \times(\text { dilution ratio })}{E_{1 \mathrm{~cm}}^{0.1 \%, 260 \mathrm{~mm}}}
$$

\subsubsection{Curative Effect of Compounds against TMV in Vivo}

Growing leaves on Nicotiana tabacum, L of the same ages were selected. TMV (concentration of $6 \times 10^{-3} \mathrm{mg} / \mathrm{mL}$ ) was dipped to inoculate the whole leaves. Then the leaves were washed with water and dried. The compound solution was smeared on the left side and the solvent was smeared on the 
right side for control. The local lesion numbers were then recorded 3-4 days after inoculation [37]. For each compound, three repetitions were conducted. The inhibition rate of the compound was then calculated according to the following formula ('av' means average):

Inhibition rate $(\%)=\frac{\left[\begin{array}{c}\text { av.local lesion numbers of control } \\ \text { (not treated with compound })\end{array}\right]-(\text { av.local lesion numbers smeared with drugs })}{\text { av.local lesion numbers of control (not treated with compound })} \times 100$

\section{Conclusions}

Polyethyleneglycol sulphonic acid $\left(\mathrm{PEG}-\mathrm{OSO}_{3} \mathrm{H}\right)$ has been successfully applied as an efficient, environmentally benign polymeric catalyst for the synthesis of a series of 14-aryl-14Hdibenzo[a,j]xanthenes through one-pot condensation reaction of 2-naphthol with various aromatic aldehydes under solvent-free conditions at $60^{\circ} \mathrm{C}$. This synthetic protocol offers several advantages, including short reaction times, solvent-free conditions, recyclability of the catalyst and high isolated yields of the products. The present investigations concluded that our synthesized xanthenes may have potential as novel chemical compounds with biologically active nitrogenous groups for the development of new anti-viral agents for controlling plant disease caused by TMV and/or other viruses. Results in our work, especially the synthesis of xanthene compounds with an eco-friendly catalyst may help to improve the method of application and possible utilization of this group of compounds in the control of plant virus diseases. Furthermore, extensive investigation in terms of the specific molecular mechanism responsible for anti-viral property of the title compounds is ongoing.

\section{Acknowledgments}

The authors are grateful to Research University Grant Scheme (RUGS), University Putra Malaysia, 43400 Serdang, Selangor, Malaysia.

\section{References and Notes}

1. Ritzenthaler, C. Resistance to plant viruses: Old issue, new answer. Curr. Opin. Biotechnol. 2005, $16,118-122$.

2. Tu, S.J.; Zhou, J.F.; Lu, Z.S.; Deng, X.; Shi, D.Q.; Wang, S.H. Condensation of Aromatic Aldehydes with 5,5-dimethyl-1,3-cyclohexanedione without catalyst. Synth. Commun. 2002, 32, 3063-3067.

3. Bailey, D.C.; Langer, S.H. Immobilized transition-metal carbonyls and related Catalysts. Chem. Rev. 1981, 81, 109-148.

4. Thompson, L.A.; Ellman, J.A. Synthesis and Applications of Small Molecule Libraries. Chem. Rev. 1996, 96, 555-600.

5. Wang, X.; Quan, Z.; Wang, F.; Wang, M.; Zhang, Z.; Li, Z. PEG-SO ${ }_{3} \mathrm{H}$ as Catalyst for 3,4-Dihydropyrimidones via Biginelli Reaction Under Microwave and Solvent-Free Conditions. Synth. Commun. 2006, 36, 451-456. 
6. Kiasat, A.; Mehrjardi, M.F. PEG-SO ${ }_{3} \mathrm{H}$ as eco-friendly polymeric catalyst for regioselective ring opening of epoxides using thiocyanate anion in water: An efficient route to synthesis of $\beta$-hydroxy thiocyanate. Catal.Commun.2008, 9, 1497-1500.

7. Wang, X.C.; Li, L.; Quan, Z.J.; Gong, H.P.; Ye, H.L.; Cao, X.F. PEG-SO ${ }_{3} \mathrm{H}$ as catalyst for the Beckmann rearrangement and dehydration of oximes.Chin.Chem. Lett. 2009, 20, 651-655.

8. Hasaninejada, A.; Shekouhya, M.; Zareb, A.; Hoseini Ghattalia, S.M.S.; Golzara, N. PEG-SO ${ }_{3} \mathrm{H}$ as a New, Highly Efficient and Homogeneous Polymeric Catalyst for the Synthesis of Bis(indolyl)methanes and 4,4'-(Arylmethylene)-bis(3-methyl-1-phenyl-1H-pyrazol-5-ol)s in Water. J. Iran. Chem. Soc. 2011, 8, 411-423.

9. Bacci, J.P.; Kearney, A.M.; van Vranken, D.L. Efficient two-step synthesis of 9-aryl-6-hydroxy3H-xanthen-3-one fluorophores. J. Org. Chem. 2005, 70, 9051-9053.

10. Knight, C.G.; Stephenes, T. Xanthene-dye-labelled phosphatidylethanolamines as probes of interfacial pH: Studies in phospholipid vesicles. J. Biochem. 1989, 258, 683-687.

11. Chibale, K.; Visser, M.R.; van Schalkwyk, D.; Smith, P.J.; Saravanamuthu, A.; Fairlamb, A.H. Exploring the potential of xanthene derivatives as trypanothione reductase inhibitors and chloroquine potentiating agents. Tetrahedron 2003, 59, 2289-2296.

12. Banerjee, A.; Mukherjee, A.K. Chemical aspects of santalin as a histological stain. Stain Technol. 1981, 56, 83-85.

13. Singh, K.; Arora, D.; Singh, S. Dowex-promoted general synthesis of $N, N^{\prime}$-disubstituted-4-aryl3,4-dihydropyrimidinones using a solvent-free Biginelli condensation protocol. Tetrahedron Lett. 2006, 47, 4205-4207.

14. Ko, S.; Yao, C.-F. Heterogeneous catalyst: Amberlyst-15 catalyzes the synthesis of 14-substituted14H-dibenzo[a,j]xanthenes under solvent-free conditions. Tetrahedron Lett. 2006, 47, 8827-8829.

15. Sarma, R.J.; Baruah, J.B. One step synthesis of dibenzoxanthenes. Dyes Pigments 2005, 64, 91-92.

16. Papini, P.; Cimmarusti, R. Action of formamide and formanilide on naphthols and on barbituric acid. Gazz. Chim. Ital. 1947, 77, 142.

17. Sen, R.N.; Sarkar, N. The condensation of primary alcohols with resorcinol and other hydroxy aromatic compounds. J. Am. Chem. Soc. 1925, 47, 1079-1091.

18. Ota, K.; Kito, T. An improved synthesis of dibenzoxanthene. Bull. Chem. Soc. Jpn. 1976, 49, 1167-1168.

19. Khosropour, A.R.; Khodaei, M.M.; Moghannian, H. A facile, simple, and convenient method for the synthesis of 14 -alkyl or aryl-14H-dibenzo[a,j]xanthenes catalyzed by $p$-TSA in solution and solvent free conditions. Synlett 2005, 2005, 955-958.

20. Rajitha, B.; Kumar, B.S.; Reddy, Y.T.; Reddy, P.; Sreenivasulu, N. Sulfamic acid: A novel and efficient catalyst for the synthesis of aryl-14H-dibenzo[a,j]xanthenes under conventional heating and microwave irradiation. Tetrahedron Lett. 2005, 46, 8691-8693.

21. Das, B.; Ravikanth, B.; Ramu, R.; Laxminarayana, K.; Rao, B.V. Iodine-catalyzed simple and efficient synthesis of 14-aryl or alkyl-14H-dibenzo[a,j]xanthenes. J. Mol. Catal. A Chem. 2006, 255, 74-77.

22. Pasha, M.A.; Jayashankara, V.P. Molecular iodine catalyzed synthesis of aryl-14Hdibenzo[a,j]xanthenes under solvent-free condition. Bioorg. Med.Chem. Lett. 2007, 17, 621-623. 
23. Nagarapu, L.; Kantevari, S.; Mahankhali, V.C.; Apuri, S. Potassium dodecatungstocobaltate trihydrate $\left(\mathrm{K}_{5} \mathrm{CoW}_{12} \mathrm{O}_{40} \cdot 3 \mathrm{H}_{2} \mathrm{O}\right)$ : A mild and efficient reusable catalyst for the synthesis of aryl-14H-dibenzo[a.j]xanthenes under conventional heating and microwave irradiation. Catal. Commun. 2007, 8, 1173-1177.

24. Bigdeli, M.A.; Heravi, M.M.; Mahdavinia, G.H. Wet cyanuric chloride catalyzed simple and efficient synthesis of 14-aryl or alkyl-14H-dibenzo[a,j]xanthenes. Catal. Commun. 2007, 8, $1595-1598$.

25. Saini, A.; Kumar, S.; Sandhu, J.S. A New LiBr-Catalyzed, Facile and Efficient Method for the Synthesis of 14-Alkyl or Aryl-14H-dibenzo[a,j]xanthenes and Tetrahydrobenzo[b]pyrans under Solvent-Free Conventional and Microwave Heating. Synlett 2006, 2006, 1928-1932.

26. Bigdeli, M.A.; Heravi, M.M.; Mahdavinia, G.H. Silica-supported perchloric acid $\left(\mathrm{HClO}_{4}-\mathrm{SiO}_{2}\right)$ : A mild, reusable, and highly efficient heterogeneous catalyst for the synthesis of 14-aryl or alkyl-14H-dibenzo[a,j]xanthenes. J. Mol. Catal. A Chem. 2007, 275, 25-29.

27. Dabiri, M.; Baghbanzadeh, M.; Nikcheh, M.S.; Arzroomchilar, E. Ecofriendly and efficient one-pot synthesis of alkyl-or aryl-14H-dibenzo[a,j]xanthenes in water. Bioorg. Med. Chem. Lett. 2008, 18, 436-438.

28. Seyyedhamzeh, M.; Mirzaei, P.; Bazgir, A. Solvent-free synthesis of aryl-14H-dibenzo[a,j]xanthenes and 1,8-dioxo-octahydroxanthenes using silica sulfuric acid as catalyst. Dyes Pigments 2008, 76, $836-839$.

29. Su, W.K.; Yang, D.; Jin, C.; Zhang, B. Yb(OTf $)_{3}$-catalyzed condensation reaction of $\beta$-naphthol and aldehyde in ionic liquids: A green synthesis of aryl-14H-dibenzo[a,j]xanthenes. Tetrahedron Lett. 2008, 49, 3391-3394.

30. Fu, G.Y.; Huang, Y.X.; Chen, X.G.; Liu, X.L. An Efficient Synthesis of 14-Aryl or Alkyl-14Hdibenzo[a,j]xanthenes Using Reusable $\mathrm{HBF}_{4}-\mathrm{SiO}_{2}$ Catalyst Under Thermal and Solvent-Free Conditions. J. Chin. Chem. Soc. 2009, 56, 381-385.

31. Nazeruddin, G.M.; Abdulkarim, M.A.A.K. Ultrasound assisted one-pot synthesis of 12-aryl8,9,10,12-tetrahydrobenzo[a]xanthen-11-one derivatives using chlorosulphonic acid as a catalyst under solvent-free conditions. Res. J. Pharm. Biol. Chem. Sci. 2011, 2, 71-76.

32. Bhattacharya, A.K.; Rana, K.C. Microwave-assisted synthesis of 14-aryl-14H-dibenzo[a,j]xanthenes catalysed by methanesulfonic acid under solvent-free conditions. Mendeleev Commun. 2007, 17, 247-248.

33. Hu, D.Y.; Wang, Q.Q.; Yang, S.; Song, B.A.; Bhadury, P.S.; Jin, L.H.; Yan, K.; Liu, F.; Chen, Z.; Xue, W. Synthesis and antiviral activities of amide derivatives containing the $\alpha$-aminophosphonate moiety. J. Agric. Food Chem. 2008, 56, 998-1001.

34. Chen, M.H.; Chen, Z.; Song, B.A.; Bhadury, P.S.; Yang, S.; Cai, X.J.; Hu, D.Y.; Xue, W.; Zeng, S. Synthesis and antiviral activities of chiral thiourea derivatives containing an $\alpha$-aminophosphonate moiety. J. Agric. Food Chem. 2009, 57, 1383-1388.

35. Hasaninejad, A.; Zare, A.; Shekouhy, M.; Rad, J.A. Sulfuric acid-modified PEG-6000 $\left(\mathrm{PEG}-\mathrm{OSO}_{3} \mathrm{H}\right)$ : An efficient, bio-degradable and reusable polymeric catalyst for the solvent-free synthesis of poly-substituted quinolines under microwave irradiation. Green Chem. 2011, 13, 958-964. 
36. Gooding, G.V.; Hebert, T.T. A simple technique for purification of tobacco mosaic virus in large quantities. Phytopathology 1967, 57, 1285.

37. Li, S.Z.; Wang, D.M.; Jiao, S.M. Pesticide Experiment Methods-Fungicide Sector; Press of China: Beijing, China, 1991; pp. 93-94.

Sample Availability: Samples of thecompounds $\mathbf{3 a - 3 i}, \mathbf{5 ,} \mathbf{6}$ and $\mathbf{9}$ are available from the authors.

(C) 2012 by the authors; licensee MDPI, Basel, Switzerland. This article is an open access article distributed under the terms and conditions of the Creative Commons Attribution license (http://creativecommons.org/licenses/by/3.0/). 